\section{Replacing foreign languages with mother tongue in education in African countries: A review of enabling and disabling factors in Tanzania}

\author{
Dady, Ntide \\ Beijing Normal University, China (ntide.dady@mnma.ac.tz)
}

Received: 6 May 2020

Revised: 27 July 2020 DOI: $10.5861 /$ ijrse.2020.5020

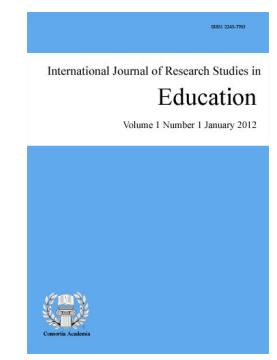

ISSN: $2243-7703$ Online ISSN: 2243-7711

OPEN ACCESS

\title{
Abstract
}

The practices of providing education in Tanzania are underpinned by the principal that it is a fundamental right and it must be made available to everyone. In the light of this principle, the government of Tanzania has taken series of measures to ensure that there is no just schooling but effective learning for all children in schools. These measures including improvement of language of instruction (LoI) with consideration that LoI not only enable students to receive, process and express information relating to their learning but it also a cornerstone for provision of quality education. Having realized this factor, the government has made several attempts of replacing foreign language (English) with popular mother tongue based language (Kiswahili or Swahili) in post primary education. However, these attempts have been remaining in policy documents without moving forward to its implementation with recently similar attempt also indicate all signs of falling into that trap. Drawing from different studies that were conducted in Tanzania and other African countries, this conceptual review aims to analyse factors that have been pulling back and pushing forward the move of African countries to draw their indigenous languages from peripherals use into central parts of education as LoI with a particular reference of Tanzania.

Keywords: language of instruction; foreign language; mother tongue based language 


\section{Replacing foreign languages with mother tongue in education in African countries: A review of enabling and disabling factors in Tanzania}

\section{Introduction}

For the past many years, the choice of language of instruction (LoI) in education has been an unending debate particularly in multilingual African countries. Two dominants opinions are on whether to adopt first language or other foreign language like English, French or Portuguese as medium of instruction in schools. Closely to that is further debate of when using first language and foreign languages (De Klerk, 2002; Tollefson, 2002). Prior to colonization, the choice of LoI was not a challenge in African countries due to the reason that each community was having its own native language that was used in educating their children. This means that the usage of a language that cut across all communities irrespective of their linguistic variations was brought by colonialism and Western education in African countries (Alidou, 2004). Since then, schools were established and students were often grouped together regardless of their language variations. Foreign languages were chosen as languages of instructions in schools as a main strategy of overcoming the challenge of multilingual in classrooms (Komba \& John, 2015). Consequently, African countries languages inherited languages of countries that colonized them. In this case, English became medium of instructions in many countries that were colonized by British including Tanzania and the same case happened to other languages in other African countries (Mazrui, 2002; Wolf \& Igboanusi, 2006).

Rubagumya (1990) notes that, after attainment of its independence, African countries took different paths in their use of official languages and LoI whereby some countries decided to use one official language and LoI and other social services. Also, some of countries opted to make multiple languages as official languages. These African countries including Nigeria Zambia and South Africa where numerous mother tongues based languages were accepted to be used for official purposes including education (Rubagumya, 1990). Nigeria in particular, made use of more than 800 indigenous languages which make a country to be leading multiethnic and multilingual country in Africa. Among these languages, eight languages were made official language as well as English and were used as LoI up to university level. In the same vein, South Africa recognized 11 languages as official language and language of teaching and learning in schools (Rubagumya, 1994).

Recently, majority of African countries are using French, Portuguese and English as LoI in schools in all classes and in some of early classes for some countries. In this context, mother tongue based language are considers as outsiders in provision of quality education in many countries (World Bank, 1995). As Mose (2017) notes, there are only eight countries that use mother tongue based language as formal LoI. These countries include Chad, Nigeria, Zimbabwe, Tanzania, Ethiopia, Somalia, Sudan and South Africa. Among these countries, Tanzania is the only country which has successfully used mother tongue based language of instruction in all grades of primary grades. The use indigenous languages have been challenged by some African scholars. These scholars pointed out that the issue of language is very complex in some countries and they have to inherit languages of their colonizers after independence as a neutral language that offer common basis (Mose, 2017). Even encouragement from international organizations to use first language in primary education was challenged by scholars like Mazrui and Mazrui (1995) with a view that this move was likely to further underdeveloped African countries. Other scholars, (e.g Bamghose, 2000), to mention but few, raises concerns on the use of African indigenous languages by put forward challenges related to shortage of books, terminologies and teachers as well as parental influences.

However, the reasons provided above have been challenged by international agencies and scholars from Africa and outside of the continent who regards it as mere arguments (Cummins, 2000; Wolf \& Igboanusi, 2006). These was done by putting together a range of studies that were conducted within Africa, America and Asia that proved how useful indigenous languages are in bring effective and efficient learning especially in elementary

52 Consortia Academia Publishing (A partner of Network of Professional Researchers and Educators) 
Replacing foreign languages with mother tongue in education in African countries

education. Given a plethora of facts and arguments that supports the use mother tongue as steering force towards provision of quality education; some of African countries for instance Tanzania embarked on a move towards the use of Kiswahili in all level of education by putting it in policy statements without moving forward to actual implementation of making Kiswahili a LoI in all levels. This is vivid in current move where the new Education and Training Policy directs Kiswahili should replace English to be LoI in all levels of education (Ministry of Education, 2014).

\subsection{Historical context of language and language in education in Tanzania}

Tanzania (officially known as the United Republic of Tanzania) is located in East Africa within African Great Lakes Region. The country was formed after unification of Tanganyika and Zanzibar in 1964. The country, like many other African countries comprised a diverse population. "There major racial groups include African (who constitute the majority), Asians (originally from Arabia and Indian sub-continent) and Caucasians (mainly British and other Europeans)" (Rwezaura, 1993, p. 31).

Tanzania has loads of first languages like many other African countries with more than 127 languages which make it the most linguistically diverse among East African countries. Kiswahili "commonly known as Swahili in the West" is the lingua franca which is spoken by majority of Tanzania the situation which distinguishes this country with other East African countries. Kiswahili is closely related with other native languages in Tanzania as they are all of Bantu origin by its vocabularies and structures and it also lend a lot of vocabularies from Arabic due to trades that were conducted between Tanzanians and Arabs (Rwezaura, 1993). Kiswahili is the first and second languages of majority of people in Tanzania. In the year 2004 it was estimated by National Kiswahili Council that Kiswahili was at least second language to almost all Tanzanians (Broke-Utne, 2005).

Tanzania was colonized by Germany and British and it was during this time when the use of Kiswahili got some official status. This happened during late $17^{\text {th }}$ century when Kiswahili was made a language of instructions in all primary schools and in colonial administration. This decision was reached after a debate of a language to be used between Kiswahili and Germany and at the end Kiswahili was chosen to be language of instructions in schools (Rubagumya, 1991). However, Roy-Campbell (2001) establish that this decision has been a subject of questions with a view that the decision that were made Germany aimed at preventing Tanzanians to learn German so that they can develop feelings of being equal with Germans. On the other hand, the main focus of education provided by Germans was to prepare Tanzanians to hold different administrative positions so Kiswahili was chosen as it was a language that majority of people could have understand during that time. This promotion of Kiswahili was a very important step for the growth of Kiswahili into a lingua franca of Tanzania (Roy-Campbell, 2001).

During British rule in Tanzania (1918-1961), they made English official language (Rubagumya, 1991). In the same vein, English was chosen by force to be a LoI and Kiswahili was completely degraded and being removed in curriculum. Difference coercive measures were taken in order to stress the use English that including punishments that was done for students who did not use particularly English in private schools (Rubagumya, 1991). Notably, the measures to promote the use Kiswahili began in 1930s when majority of people used it in their communications. During this time, Inter-Territorial Language Committee was established and it was mainly in charge of standardizing the use of Kiswahili and produced learning materials including dictionaries and books in East Africa (Vavrus, 2002). Then, the former President and father of the nation the late Julius Nyerere took measures of making Kiswahili a pan-Tanzania language. He used Kiswahili in his campaigns for political freedom by uniting and mobilizing mass of people from all corners of the country (Rubagumya, 1990). From this move we can get a lesson that "African languages have the same potential to serve as a pan-national language as any other language, and unification can be made to happen if there is political will to create and enforce the necessary policies and strategies" (Babaci-Wilhite, 2013, p. 5).

During independence Kiswahili has already been accepted as a unifying and widely acceptable language, as 
Rwezaura, (1993, p. 32) notes, "It cannot be doubted therefore, that by independence in 1961, Kiswahili had attained a high degree of political prestige as well as wide acceptability in the whole country. Even more significantly, Kiswahili was not clearly associated with a particular ethnic group and hence its use did not provoke any of the political problems associated with ethnic domination". After attainment of its independence, the use of Kiswahili continued to be supported by government under the leadership of the first president Nyerere as well political parties "Chama cha Mapinduzi (CCM) or Party of the Revolution and Tanganyika African National Union (TANU) (Vavrus, 2002, p. 357). He further clarify that President Nyerere visited a parliament and he delivered his speech in Kiswahili where he insisted the use of Kiswahili in offices. In due course, Kiswahili was made to be recognized as a national language. In the same vein, it was language of communication in government and became LoI in primary schools.

The use of Kiswahili as LoI in primary education was planned to be extended up to the first two years of secondary education by 1973 (Rubyaguma, 1990). Different policy makers were interested to replace English with Swahili in secondary education. In 1978 the study of Mlama and Materu that was commissioned by National Kiswahili Council put forward concerns on existing language policy and they look forward for language transformation (Lwaitama \& Rugemalira, 1990). In 1992, the Presidential Commission on Education recommended Kiswahili to be LoI in secondary by 1985 (Lwaitama \& Rugemalira, 1990).

While majority of stakeholders started to change their minds based on these recommendations, however, there were no immediate action that was taken to effect the recommendations put forward by Presidential commission (Rwezaura, 1993). Then, the Ministry of Education released official relating to the LoI that "Both languages, English and Kiswahili, will be used as media of instruction and English will be improved at all levels of education" (Ministry of education cited in Lwaitama \& Rugemalira, 1990, p. 37). In the same year, President Nyerere gave a speech that stressed that English will continue to be language of instruction in schools in order to motivate and value the language in Tanzania (Lwaitama \& Rugemalira, 1990).

Since independence to date, the structure of official language use and LoI has remained the same in Tanzania. In education system, students start to use Kiswahili as LoI in primary education and thereafter change to English in the entire post primary education. This system has been seen as an obstacle for provision of quality education necessary for the development of the country (Yogi, 2017). The main concern is fact that primary education cultivates students who are not adequately prepared to have command of English language which makes difficulties for them to do well in post primary studies where English is used as LoI. In the midst of these controversial, researchers and educational stakeholders called for changes by starting using Kiswahili as medium of instruction in all levels of education (Tibategeza \& Plessis, 2018).

As a response, the Government of United Republic of Tanzania released 2014 Education and Training Policy on 13/ February/2015. The document provides a range of directions which aiming at enabling attainment of development goals including provision of quality education. In chapter three, the policy discusses about national languages and LoI. According to this policy, Kiswahili should be a LoI in all levels of education. On the other hand, the document acknowledges the importance of English and other foreign language due its high value at national, regional and international levels. Hence, the policy stipulates that the Government will strengthen the use of English language in teaching and learning in all levels of education but not as LoI (Ministry of education and Culture, 2014).

This move implies that, English is going to be replaced with Kiswahili as a LoI in all levels of education. When looking on push factors behind this transformation, we can find a plethora of empirical studies that advocating the need of using Kiswahili as a LoI in all levels of education as a mechanism of assuring effective teaching and learning and overall quality of education (Rubagumya 2003; Mpemba, 2007; Bikongoro, 2015). Closely to that, it is need of strengthening the usage of Kiswahili at national and international levels considering that Kiswahili language is one of the national treasures that need to be valued and embraced. It was viewed that the language has grown enough at international level to the extent that it can enable people to get knowledge and 
Replacing foreign languages with mother tongue in education in African countries

skills in many areas including science and technology (Ministry of education and Culture, 2014).

However, it have been now five years since the Government launched the 2014 Education and Training Policy and Kiswahili is not yet used as a medium of instruction in post primary education which is contrary to what was stipulated in policy regarding LoI. When recalling Presidential commission of 1982 that suggested similar move for improvement of education in Tanzania, we can realize that this vision has existed for the past many years without being implemented. This implies that this unending dream of transition of changing a LoI, in this case, from foreign language (English) to first language (Kiswahili) have a lot of complications and challenges that acts as pulling factors and at the same time there is a range of factors that necessities the need of using first languages in education, the main inquiry of this review was done in the light of this situation in Tanzania with a consideration if Tanzania will succeed in this move it will be the first country in Africa to use its mother tongue based language in education.

\subsection{Objectives of the study}

This study seeks to analyse factors that have been pulling and pushing the move of replacing foreign languages with mother tongue based language in education in African countries with a particular reference of Tanzania. It mainly draws on empirical studies that have been conducted in Tanzania and other African countries. The review was guided by the following lines of inquiry:

$>\quad$ What factors pushing forward the use of mother tongue based language in education in Tanzania and other African countries?

$>\quad$ What factors draws back attempts of using mother tongue based language in education in Tanzania and other African countries?

\section{Methodology}

Methodological part of this study was tailored under qualitative review technique (Green, Johnson, \& Adams, 2006). The process of review was done on articles whereby different electronic databases were accessed to accomplish this task. Reviewed electronic databases included but not confined to ProQuest, ScienceDirect, SAGE and JSTOR. Moreover, an author also included articles which were not from these electronic databases that were extracted from websites. The process of searching for pertinent articles were governed by key words whereby the author used key words including Tanzania, language of teaching and learning, Kiswahili language, English language, Kiswahili as a medium of teaching and learning and English as a medium of teaching and learning. Thereafter, different articles were found and the author carefully read the abstracts of all papers in order to come up with a final list of relevant articles. The process of finding final list of articles was carried out in the light of Weed's Methodological Guidelines for Review Papers (1999). The guideline establishes criteria of choosing appropriate documents for review with a consideration of criteria such as time of publication, form of publication (conference proceedings, peer reviewed), study. Ultimately, final list comprised 16 articles that explained about language of teaching and learning in Tanzania and other post-colonial countries and it served as a sole fountain of information that were required in this study. Table 1 below is the summary of the reviewed articles with information on authors as well as titles of the articles and reports.

\section{Table 1}

Summary of the reviewed articles

\begin{tabular}{cll}
\hline No & \multicolumn{1}{c}{ Author(s) } & \multicolumn{1}{c}{ Article } \\
\hline 1 & $\begin{array}{l}\text { Altinyelken, Moorcroft, \& van } \\
\text { der Draai (2014) }\end{array}$ & $\begin{array}{l}\text { The dilemmas and complexities of implementing language-in education } \\
\text { policies: Perspective from urban and rural contexts in Uganda } \\
\text { Babaci-Wilhite (2013) } \\
\text { Local languages of instruction as a right in education for sustainable } \\
\text { development in Africa } \\
\text { Learners' success in mother tongue based classroom instruction and the } \\
\text { attitudes and perceptions of school communities }\end{array}$ \\
\hline
\end{tabular}


Dady, N.

\begin{tabular}{|c|c|c|}
\hline No & Author(s) & Article \\
\hline 4 & Bikongoro $(2015)^{* *}$ & $\begin{array}{l}\text { The relevance of language policy for instruction and assessment of secondary } \\
\text { education in Tanzania: A Comparative analysis between the former Swahili } \\
\text { and English medium students }\end{array}$ \\
\hline 5 & Brock-Utne (2010) & Research and policy on the language of instruction issue in Africa \\
\hline 6 & Brock-Utne (2012) & $\begin{array}{l}\text { Language policy and science: Could some African countries learn from some } \\
\text { Asian countries? }\end{array}$ \\
\hline 7 & Desai (2016) & $\begin{array}{l}\text { Learning through the medium of English in multilingual South Africa: } \\
\text { enabling or disabling learners from low income contexts? }\end{array}$ \\
\hline 8 & $\begin{array}{l}\text { Ndamba, van Wyk, \& Sithole } \\
\text { (2017) }\end{array}$ & $\begin{array}{l}\text { Competing purposes: Mother tongue education benefits versus economic } \\
\text { interests in rural Zimbabwe }\end{array}$ \\
\hline 9 & Nomlomo \& Vuzo (2014)** & $\begin{array}{l}\text { Language transition and access to education: experiences from Tanzania and } \\
\text { South Africa }\end{array}$ \\
\hline 10 & Rubanza (2002)** & Competition through English: The failure of Tanzania's language policy \\
\hline 11 & Spernes (2012) & I use my mother tongue at home and with friends-not in school \\
\hline 12 & Swilla $(2009)^{* *}$ & $\begin{array}{l}\text { Languages of instruction in Tanzania: Contradictions between ideology, policy } \\
\text { and implementation }\end{array}$ \\
\hline 13 & Tawiah-Mensah (2019) & $\begin{array}{l}\text { The bilingual factor: Strategies to support teachers in the implementation of the } \\
\text { mother tongue-based bilingual medium of instruction in Ghana }\end{array}$ \\
\hline 14 & Tibategeza \& Plessis $(2018)^{* *}$ & $\begin{array}{l}\text { The Prospects of Kiswahili as a medium of instruction in the Tanzanian } \\
\text { education and training policy }\end{array}$ \\
\hline 15 & Wolf \& Igboanusi (2006) & $\begin{array}{l}\text { Empowerment through English-a realistic view of the educational promotion of } \\
\text { English in post-colonial contexts }\end{array}$ \\
\hline 16 & Yogi $(2017) * *$ & Kiswahili or English: A policy analysis of language instruction in Tanzania \\
\hline
\end{tabular}

\section{Findings and discussion}

This section presents and discusses findings basing on collected information (reviews), this was done responding to the two questions that guided this review in the form of following themes:

\subsection{Factors that pushing forward the use of mother tongue based language in education in Tanzania and other}

\section{African countries}

Context of learning foreign languages in schools and out of schools-The contexts in which majority of children learn foreign languages in most of African countries are not favorable for acquisition of second language. In relation to this, an example was cited by Desai (2016) on immigrant children in countries like United Kingdom and United States who learn English in ideal contexts for effective learning of language. In these settings children have wider exposure on English whereby people who surrounding them use it all time so children learn by hearing them when they are homes, schools, churches, playgrounds and other settings where their entire interactions are conducted in English.

Conversely, majority of children in Tanzania in particular and other African countries in general have been facing a daunting challenge of switching from using mother tongue based language in their daily life to foreign language in schools which has been a challenge for students in many African countries over years (Tawiah-Mensah, 2019). They only encounter foreign languages in formal settings like schools and offices while communications in environments likes schools, churches, playgrounds are done by mother tongue based language (Brock-Utne, 2010). This has caused majority of students to go to their schools with poor foundation of foreign languages which makes difficulty for them to learn it and be confident users as most of them comes to schools with backgrounds of other languages (Brock-Utne, 2010). The same case applies to Tanzania where Kiswahili is used as a first or second language by more than $95 \%$ of people and nearly all Tanzanians (99\%) can speak this language Also, it is easy for majority of children to learn Kiswahili as they acquire it beside their ethnic languages which most of them are similar to Kiswahili as they all of Bantu origin which simplify the process of learning Kiswahili (Batibo, 1995 cited in Tibategeza \& Plessis, 2018).

As a result, Rubanza (2002), compared the usage of English language among student in Tanzania as their 
school uniform whereby students use it when they are in schools and they cannot use it when they return back home. This is because majority of them are living in communities where English has no place. Back in the year 1984, Cripper and Dodd conducted a survey and reported that only $1 \%$ of students in secondary schools were in adequate level of using English language as a medium of communication in their studies in Tanzania. Similar to Tanzania, Broke-Utne (2000) cites another example of Namibia where English was made a LoI in many schools while it is only used by minority of people (1\%). It is surprising to note that, large amount of newspapers in Namibia are published in English language. She put forward that this situation indicates majority of people are remained informed about important issues that goes on their countries and only few people from elite group are the one who benefited by getting information in daily newspapers.

Positive results from empirical studies-The adoption of mother tongue based language-MOI has been supported by many empirical studies that reported the significant effects of using mother language on effective learning in Tanzania and other countries (see Bikongoro, 2015; Brock-Utne, 2010; Desai, 2016; Nomlomo \& Vuzo, 2014; Tawiah-Mensah, 2019). Prophet and Dow (1994) did a study in Botswana where a set of concepts of science were taught by using Setswana to an experimental group and similar concepts were taught to a control group by using English. The researchers investigated the understanding of these concepts and reported that students in junior secondary schools (Form 1) who were taught by using Setswana they understood well the concepts than their fellow students who were taught in English. Also, Mammimo (1995) did an experiment at the National University of Lesotho whereby students who incorrectly wrote statements in Chemistry examination were asked to express their views on similar examined content by using their mother tongue, and then the contents were translated by someone who understands that language into English. Then it was observed that their answers matched with reasonable Chemistry in many cases. This implies that, those students understood the concepts but fails to express it correctly by using English. In similar case, Bamghose (2005) reported a Yoruba experiment which was carried out in Nigeria. In this experiment it was reported that students who were taught in Yoruba over a long period of time performed well in their subjects which including English than those who were shifted in classrooms that were instructed in English after completion of their first three years of primary education.

The influence of international agencies-The use of mother tongue based language in education has been a topic of concern for international agencies; such UNESCO and UNICEF that emphasizes the use mother tongue as a gear towards effective learning and means of ensuring that children have the right to education without any discrimination. The advocacy on usage of mother tongue in teaching and learning is an example of education design of these two international organizations whose policies and practices have been directed towards right to education (Tibategeza \& Plessis, 2018; Tawiah-Mensah, 2019). The emphases of international organizations are based on the reason that most of developing countries including Tanzania and other African countries are characterized by multilingual communities however most of their schools are taught by foreign languages (Tawiah-Mensah, 2019). Such system is known as submersion; a system where teaching and learning is conducted in languages which are not used by students and it is like holding a child under water by force (Skutnann-Kangas, 2000 cited in Kadhka, 2018). In this context, international agencies put forward that students who understand the language used in teaching and learning are in good position to follow instructions of their teachers and can acquire knowledge from different sources. Also, students can be active, interactive and participative in their learning which is a solid ground for understanding of subject matters. All these can be achieved when students, teachers and parents understand the LoI and it became possible for all them to play part in development of students and schools at large which forms a base for provision of quality education in schools (Brock-Utne, 2010; Ndamba et al., 2017).

Inadequacy Proficiency of Teachers in English-Yogi (2017) mentioned inadequacy proficiency of teachers in English as another factor that necessities adoption of using mother tongue based language in education in African countries. He holds view that this has made the problem of using English as medium of teaching and to be impenetrable in Tanzania because students cannot comprehend information that they receive from their teachers. Hence, teachers often opt to teach by using Kiswahili because by using this language they can 
understand each other with their students. Worse still, all formal communication and assessments in schools has to be executed in English language. Consequently, Allen (2008) notes that it has been difficulty for majority of teachers to teach English and most of them refuse to teach. In situation where they are forced to teach it teachers tend to teach it with low morale and they may not teach all classes as required in curriculum.

\subsection{Factors that draws back attempts of using mother tongue based language in education in Tanzania and} other African countries

Resistance from education stakeholders-The idea of introducing mother tongue based language in teaching and learning received criticism from some of education stakeholders and pull back attempts of using mother tongue based language as LoI in some post-colonial countries including Tanzania. In relation to this situation, Swilla (2009) reported that the use of Kiswahili which is a mother tongue for majority of Tanzania has not yet being positively received by elite groups of people in Tanzania including high government officials and entrepreneurs. This can be seen in primary education where Kiswahili is used as a LoI while private primary schools use English as LoI. In this context, many parents who are high government officials and entrepreneurs prefer to send their children in private schools and remedial classes so that they can learn English and paying large amount of money which can be afforded at all by ordinary people (Swilla, 2009). Also, proficiency in English is used as a criterion of securing employment in highly paid positions in giant organizations. In this case, many students and parents prefer English as an ideal preparation and added advantage of competing in favorably working positions (Morrison \& Lui, 2000). The view of English as linguistic capital was the reason for rejection and challenge of using mother tongue based language in some countries including Nepal, Hong Kong, India, Botswana and Ivory Coast (Kaijage, 2000).

Likewise, studies that were conducted on LoI in Uganda indicate that the adoption of local languages brought many positive results to students. These languages were used in some regions of the country especially those which are located in rural areas. In these areas, the uses of mother tongue based languages were accepted by pupils and teachers as it influences effective and efficient learning. Surprisingly, parents were not ready to use mother tongue based languages in instructing their children in schools and they rejected it by forcing to avoid putting into effect the policy of using mother tongue based language in schools (Altinyelken et al., 2014). In the same vein, it was reported that the use of mother tongue based language was marginalized in Kenya. In relation to this, it was reported that they use of mother tongue based languages was not welcomed in schools as it was done in Kiswahili and English. While this was happening, students were more confident when using mother tongue based languages and they were more active and expressed to understand their lessons. The situation went far as the use mother tongue based languages were prohibited and punishments were used for students who use it in schools (Spernes, 2012).

Cost of producing new teaching and learning materials-High cost embedded in changing and production of new teaching and learning materials is another factor that hinders adoption of mother tongue based language in teaching and learning in African countries. Tibategeza and Plessis (2018) note that the process of replacing English language with Kiswahili has been discourage by education stakeholders with to a reason that most of teaching and learning resources available in Tanzania have been written in English. So, it will be difficult for teachers to get basic learning resources when teaching in Kiswahili. In finding way to this challenge, stakeholders were reminded about importance of using locally produced materials but they did not agree with such recommendation with a view that such kind of process cannot be accomplished on time so they keep on insisting how resources in English language was still important (Tibategeza \& Plessis, 2018).

In relation to this, we can recall the Kenya Education Commission referred to as Ominde report of 1964, which reported that it was not easy to start using Kiswahili as a LoI at that particular time due to high cost that was required to translate books and other important teaching materials to Kiswahili (Republic of Kenya, 1964). The consideration of translating learning materials is done with a primary reason that in current world, knowledge is power of winning in competitive economic environment, so it is important to read academic papers, 
Replacing foreign languages with mother tongue in education in African countries

books and scientific journals which most of them are written in English as observed by (Nunan, 2003). Also, according to Institute of Scientific Information, 90 percent of social science journals and 95 percent of science journals partially and completely use English (Lillis \& Curry, 2010).

The power of English language in economic development-The prominence of English in current globalized world cannot be overemphasized. The language is used in many countries across the world and its usage are linked with prestige, civilization and power (Altbach, 2004). African countries have realized this and they are taking actions and all possible means of helping their students to acquire skills of this, particularly, by making it a LoI in schools. This move is done with a consideration that many of African countries are in course of developing their economies and they turn into English language as a vehicle for realizing this mission. English is known to be a language of commerce at global level and African countries are using it to build international trade partnership, attract foreign investors and extending tourism activities. English language is also used in expanding exports of commodities and good from Africa. In tourism sector which is important source of economic growth of many African countries English is also needed to attract large number of tourists by the leaders who organize different logistics and programs as well as for workers who guide tourists. For instances, Rwanda started to use English as language in schools in recent years. The leaders explained it vividly they opted to use so as to open economic doors and attract many foreign from developed countries whom majority of them speak English (McGreal, 2009).

\section{Conclusion and recommendations}

In the context of past, present and future Tanzania, ideal language of teaching and learning was needed, it is needed and it will be needed as a powerful tool for delivering knowledge and skills which is important component in provision of quality education. The choice of suitable language of teaching and learning serves as foundation stone in successfully attainment of quality education; this is due to the primary reason that language is solely means of disseminating knowledge (Dube \& Ncube, 2013). In this regard, it is very imperative for the Government of the United Republic of Tanzania to give due attention to the choice of LoI in order to realize its vision of building economic competitive nation by using education.

It is very important to note that the sociolinguistic situation of Tanzania is stable when compared to neighboring and other African countries. Therefore, strengthening effective use of both Kiswahili and English as LoI is something which need close attention than a movement of altering languages used in education. This needs to be done with a consideration that the government noticed deficiency in mechanisms of teaching both languages in Tanzania (Ministry of Education and Culture, 2014). By having well improved mechanisms of teaching English and Kiswahili, it means that students will be fluent in both languages which will be ideal move of enabling the nation to attain its vision of becoming middle income country by 2025 . The most important thing to considered should be that the improvement of using English should not affect the use of Kiswahili as Jay (2001) warns that the growth of English at global level is threatening to abolish the use of mother tongue based language and cultures. In this regard, the improvement of English should be parallel with Kiswahili as insisted in 2014 Education and training Policy.

As long as students were able to learn and master mother tongue based language, in this case Kiswahili, they are likely to be fluent in second language, in this case English. This view is supported by the Affective Filter Hypothesis theory which explains that, there are individual rates of learning second language whereby other people can acquire skills of second language while other cannot even when all of them are exposed to the same environment of learning second language. This theory proposed affective filter which is kind of internal processing system which automatically screens incoming information basing on attitude, motivation, emotional states and needs of learners. In this regard, a range of negative factors will prevent input which learners receive and in turn affecting their progress of second language (Krashen, 1982). The learning of English language among students in Tanzania is surrounded by factors which affect progress of students, these including inadequate of facilities, poor teaching methods and limited use of language in their daily conversation. For instances, one the 
Head of Secondary school revealed that only three among all of his 45 teachers were having good command of English necessary for effective teaching and interactions with students (Qorro, 2002). The situation is worse in public schools as a result some of the parents opt to send their children to private schools at very high costs which cannot be afforded by majority of parents (Suma \& Rajan, 2006 as cited in Yogi, 2017).

While appreciating valuable recommendations of many studies that favored Kiswahili to be a medium of teaching and learning in all levels of education, given a reason that effective teaching and learning cannot be done by using English language, this paper suggests improvement of teaching and learning of English at lower levels so to provide students with solid foundation of communicating in English and hence enable to them to use it fluently in their post primary education. This will help them to understand concepts which are taught in their studies and hence cultivate students who are well prepared to compete at national, regional and global levels. Hence, it should not be a race of Kiswahili against English, and vise verse but a race of preparing good environment of using both languages for bright future of the country.

Hence, the focus and attention paid in discussing and debating on whether to use English or Kiswahili as a LoI in all levels should be redirected on how to improve the use of both languages and in turn making presence of both languages an asset rather than a problem. On one hand, this can be a perfect move of heightening the use of Kiswahili inside and outside of Tanzania with a consideration that it has deep rooted cultural, historical and political ties in Tanzania. On the hand, effective teaching and learning of English language will key ingredient in cultivating students who can competent at international level and playing active role of helping a country realize its vision of become a middle income country in the near future.

\section{References}

Alidou, H. (2004). Medium of instruction in post-colonial Africa: Medium of instruction policies. Lawrence Erlbaum Associates.

Allen, K. (2008, August 18-19). Primary school teachers and the problems faced with teaching the English language [Paper presentation]. The Forum on Community of Practice of Learner Centered Learning in Tanzania, Kurasini, Tanzania.

Altbach, P. G. (2004). Globalisation and the University: Myths and realities in an unequal world. Tertiary Education and Management, 10, 3-25. https://doi.org/10.1080/13583883.2004.9967114

Altinyelken, H. K., Moorcroft, S., \& van der Draai, H. (2014). The dilemmas and complexities of implementing language-in education policies: Perspectives from urban and rural contexts in Uganda. International Journal of Educational Development, 36, 90-99. https://doi.org/10.1016/j.ijedudev.2013.11.001

Babaci-Wilhite, Z. (2013). Local languages of instruction as a right in education for sustainable development in Africa. Sustainability, 5, 1994-2017. https://doi.org/10.3390/su5051994

Bachore, M. M. (2014). Learners' success in mother tongue based classroom instruction and the attitudes and perceptions of school communities. International Journal of Sociology of Education, 3(2), 118-135.

Bamghose, A. (2000). Language and exclusion: The consequences of language policies in Africa. Münster.

Bamghose, A. (2005). Mother tongue education: Lessons learnt from the Yoruba experience. In B. Brock-Utne \& R. K. Hopson (Eds.), Languages of instruction for emancipation: Focus on postcolonial contexts and consideration (pp. 231-255). Mkuki na Nyota.

Bikongoro, P. F. (2015). The relevance of language policy for instruction and assessment of secondary education in Tanzania: A Comparative analysis between the former Swahili and English medium students. African Educational Research Journal, 3(1), 1-8.

Brock-Utne, B. (2000). Whose education for all? Recolonization of the African mind. Falmer Press.

Brock-Utne, B. (2005). The continued battle over Kiswahili as the language of instruction in Tanzania. Mkuki na Nyota.

Brock-Utne, B. (2010). Research and policy on the language of instruction issue in Africa. International Journal of Educational Development, 30(6), 636-645. https://doi.org/10.1016/j.ijedudev.2010.03.004

Brock-Utne, B. (2012). Language policy and science: Could some African countries learn from some Asian 
Replacing foreign languages with mother tongue in education in African countries

countries? International Review of Education, 58, 481-503. https://doi.org/10.1007/s11159-012-9308-2

Criper, C., \& Dodd, W. (1984). Report on the teaching of the English language and its use as a medium of education in Tanzania. Ministry of National Education.

Cummins, J. (2000). Language, power and pedagogy: Bilingual children in crossfire. Clevedon. https://doi.org/10.21832/9781853596773

De Klerk, V. (2002). Language issues in our schools: Whose voice counts? Perspectives in Education, 20(1), $1-14$.

Desai, Z. (2016). Learning through the medium of English in multilingual South Africa: Enabling or disabling learners from low income contexts? Comparative Education, 52(3), 343-358. https://doi.org/10.1080/03050068.2016.1185259

Dube, L., \& Ncube, B. (2013). Language policy and linguistic rights in post-colonial Zimbabwe: The case of IsiNdebele. Greener Journal of Social Sciences, 3(5), 249-255. https://doi.org/10.15580/GJSS.2013.5.030413511

Green, B. N., Johnson, C. D., \& Adams, A. (2006). Writing narrative literature reviews for peer-reviewed journals: Secret of the trade. Journal of Chiropractic Medicine, 5(3), 101-117. https://doi.org/10.1016/S0899-3467(07)60142-6

Jay, P. (2001). Beyond discipline? Globalization and future of English. Modern Language Association of America, 116(1), 32-47.

Kadhka, B. K. (2018). Mother tongue education: A quest of quality and access in education. Journal of NELTA Surkhet, 5, 65-74. https://doi.org/10.3126/jns.v5i0.19489

Kaijage, E. S. (2000). Faculty of commerce and management graduates and their employers: A tracer study. University of Dar es Salaam.

Komba, S. C., \& John, D. (2015). Investigation of pupils' English language abilities in Tanzania: The case of English medium primary schools. World Journal of English Language, 5(1), 56-64. https://doi.org/10.5430/wjel.v5n1p56

Krashen, S. (1982). Principles and practice of second language acquisition. University of Southern California.

Lillis, T., \& Curry, M. (2010). Academic writing in a global context. The politics and practices of publishing in English. Rutledge.

Lwaitama, A. F., \& Rugemalira, J. M. (1990). The English language support project in Tanzania. Language in Education in Africa: A Tanzanian perspective. Multilingual Matters.

Mammimo, L. (1995). Teaching/learning theoretical chemistry at undergraduate level. Southern Africa Journal of Mathematics and Science Education, 2, 1-2.

Mazrui, A. A., \& Mazrui, A. M. (1995). Swahili, state and society: The political economy of an African language. East African Educational Publishers.

Mazrui, A. M. (2002). The English language in African education: Dependency and decolonization. In J. W. Tollefson (Ed.), Language policies in education: Critical issues (pp. 267-281). Lawrence Erlbaum Associates.

McGreal, C. (2009, January 15). Why Rwanda said adieu to French. The Guardian.

Ministry of Education and Culture Tanzania. (2014). Education and training policy. Retrieved from http://webcache.googleusercontent.com/search?q=cache:http://www.tanzania.go.tz/egov/uploads/docum ents/education_and_Training_Policy_sw.pdf

Morrison, K., \& Lui, I. (2000). Ideology, linguistic capital and the medium of instruction in Hong Kong. Journal of Multilingual and Multicultural Development, 21(6), 471-486.

https://doi.org/10.1080/01434630008666418

Mose, P. N. (2017). Language-in-education policy in Kenya: Intention, interpretation, implementation. Nordic Journal of African Studies, 26(3), 215-230.

Mpemba, T. (2007). Tanzanian policy makers' reluctance to sanction Kiswahili instructional medium in post-primary education: How do learners and instructors cope with or resist the English medium policy? [Unpublished thesis]. University of Dar es Salaam, Dar es Salaam, Tanzania.

Ndamba, G. T., van Wyk, M. M., \& Sithole, J. C. (2017). Competing purposes: Mother tongue education benefits 
versus economic interests in rural Zimbabwe. The International Indigenous Policy Journal, 8(1), 1-21. https://doi.org/10.18584/iipj.2017.8.1.1

Nomlomo, V., \& Vuzo, M. (2014). Language transition and access to education: Experiences from Tanzania and South Africa. International Journal of Education Studies, 1(2), 73-82.

Nunan, D. (2003). The Impact of English as a global language on educational policies and practices in the Asia-Pacific region. TESOL Quarterly, 37(4), 589-613. https://doi.org/10.2307/3588214

Prophet, B., \& Dow, D. (1994). Mother tongue language and concept development in science: A Botswana case study. Language, Culture and Curriculum, 7(3), 205-216. https://doi.org/10.1080/07908319409525178

Qorro, M., (2002, May 21). Language of instruction not determinant in quality education. The Guardian.

Republic of Kenya. (1964). Kenya education commission report. Government Printer.

Roy-Campbell, Z. (2001). Empowerment through language. Africa World Press.

Rubagumya, C. M. (1990). Language in Tanzania. Language in education in Africa: A Tanzanian perspective. Multilingual Matters.

Rubagumya, C. M. (1991). Language promotion for educational purposes: The example of Tanzania. International Review of Education, 37(1), 67-85. https://doi.org/10.1007/BF00598168

Rubagumya, C. M. (1994). Teaching and researching languages in African classrooms. Multilingual Matters.

Rubagumya, C. M. (2003). English medium primary schools in Tanzania: A new 'Linguistic market' in education. In B. Brock-Utne, M. Qorro, \& D. Desai (Eds.), Language of instruction in Tanzania and South Africa (pp. 149-169). E \& D Ltd.

Rubanza, Y. I. (2002). Competition through English: The failure of Tanzania's language policy. In K. K. Prah (Ed.), Rehabilitating African languages (pp. 39-51). The Centre for Advanced Studies of African Society.

Rwezaura, B. (1993). Constraining factors to the adoption of Kiswahili as a language of the law in Tanzania. Journal of African Laws, 37(1), 30-45. https://doi.org/10.1017/S0021855300011098

Spernes, K. (2012). I use my mother tongue at home and with friends-not in school. Multilingualism and identity in rural Kenya. Language, Culture and Curriculum 25(2), 189-203. https://doi.org/10.1080/07908318.2012.683531

Swilla, I. N (2009). Languages of instruction in Tanzania: Contradictions between ideology, policy and implementation. African Study Monographs, 30(1), 1-14.

Tawiah-Mensah, J. E. (2019). The bilingual factor: Strategies to support teachers in the implementation of the mother tongue-based bilingual medium of instruction in Ghana. International Journal of Creative Research and Studies, 3(5), 48-58

Tibategeza, E. R., \& Plessis, T. (2018). The prospects of Kiswahili as a medium of instruction in the Tanzanian education and training policy. Journal of Language and Education, 4(3), 88-98. https://doi.org/10.17323/2411-7390-2018-4-3-88-98

Tollefson, J. W. (2002). Critical issues in educational language policy. In J. W. Tollefson (Ed.), Language policies in education: Critical issues (pp. 256-260). Lawrence Erlbaum Associates.

Vavrus, F. (2002). Postcoloniality and English: Exploring language policy and the politics of development in Tanzania. TESOL Quarterly, 36(3), 373-397. https://doi.org/10.2307/3588418

Wolf, H., \& Igboanusi, H. (2006). Empowerment through English-a realistic view of the educational promotion of English in post-colonial contexts: The case of Nigeria. LAUD Linguistic Agency.

World Bank. (1995). 1995 World Bank report. Education in Sub-Saharan Africa, Policies of adjustments, revitalisms and expansion. WB Press.

Yogi, M. C. (2017). Kiswahili or English: A policy analysis of language instruction in Tanzania. Capstone Collection. 